\title{
Learning approaches in accounting education: Towards deep learning
}

\author{
Yeng Wai Lau ${ }^{\mathrm{a}^{*}}$ and Shi Yee Lim
}

${ }^{a}$ Senior Lecturer, Faculty of Economics and Management, Universiti Putra Malaysia, Malaysia ${ }^{b}$ Graduate, Faculty of Economics and Management, Universiti Putra Malaysia, Malaysia

\begin{tabular}{|c|c|}
\hline C H R O N I C L E & A B S T R A T T \\
\hline $\begin{array}{l}\text { Article history: } \\
\text { Received March 25, } 2015 \\
\text { Received in revised format June } \\
12015 \\
\text { Accepted June } 192015 \\
\text { Available online } \\
\text { June } 242015 \\
\text { Keywords: } \\
\text { Deep learning } \\
\text { Strategic learning } \\
\text { Surface learning } \\
\text { Accounting education } \\
\text { Higher education }\end{array}$ & $\begin{array}{l}\text { Deep learning facilitates development of generic skills pertinent to prepare graduates for } \\
\text { employment. Accounting education with syllabuses burdened with accounting standards to be } \\
\text { memorized and regurgitated in examinations does little to promote deep learning. This study } \\
\text { conducted a questionnaire survey to examine the extent to which accounting undergraduates at } \\
\text { a public university in Malaysia adopt deep learning. This study demonstrates that deep learning } \\
\text { is not readily attainable. Surface learning, which promotes rote memorization, constitutes a } \\
\text { stepping stone towards deep learning. Having a preference or thirst for meanings is also } \\
\text { pertinent to motivate undergraduates to move from rote memorization to seek meanings and } \\
\text { thus deep learning. Female undergraduates have been found to be more inclined to adopt deep } \\
\text { learning. Much is still to be learned on how best to promote deep learning as learning is a life- } \\
\text { long process where everyday life experiences, both on and off-campus, facilitate learning and } \\
\text { development. }\end{array}$ \\
\hline
\end{tabular}

\section{Introduction}

Concerns about business schools' increasing disconnection from practice and the resultant graduate unemployment as graduates are ill-equipped with the relevant skills to be employable are not new (Marton et al., 1984; Entwistle, 1987, 1988; Entwistle \& Tait, 1990; Bennis \& O’Toole, 2005; Cleary et al., 2007; Eckhardt \& Wetherbe, 2014). To what extent business schools prepare graduates for employment is indeterminate. On one hand, employers have been found to be satisfied with graduates' employability skills to a certain extent (e.g. Lowden et al., 2011). Development of employability skills has also been found to be a life-long process where business schools are not solely responsible for preparing graduates for employment (e.g. Cleary et al., 2007). On the other hand, accounting education has been contended to promote rote memorization (Beattie et al., 1997; Newble \& Entwistle, 1986; Sunder, 2010), which does little to facilitate development of generic employability skills such as critical thinking and problem solving.

\footnotetext{
* Corresponding author. Tel: +603 89467873 Fax:+603 89486188

E-mail address: wai_ly@upm.edu.my (Y.W. Lau) 
This study contributes by examining accounting undergraduates' learning approaches. More specifically, this study examines to what extent accounting undergraduates seek to understand (i.e. deep learning) versus memorize facts (i.e. surface learning). Accounting education constitutes a rich context to ascertain to what extent undergraduates learn with understanding when confronted with volumes of written standards to be covered in lectures leaving little room for critical discussions and reflections on the merits of accounting alternatives (Sunder, 2010).

Extant literature suggests that there are three predominant approaches to learning: deep, surface and strategic learning (see Richardson, 2005). Deep learning is characterized by quest for meanings, which involves vigorous interaction with the subject being studied, relating new ideas and concepts to existing knowledge and everyday experiences, and critical evaluation of evidences to conclusions and logic of arguments. Surface learning is characterized by passive rote memorization where focus is on task completion. Surface learning entails little appreciation of the purposes of learning where learning is perceived as an imposition resulting in failure to distinguish principles from examples and inability to integrate new information with existing knowledge to be applied in everyday life experiences. Strategic learning is characterized by concern to achieve the highest possible grades. Strategic learning involves analyzing structure and content of past examinations to predict examination questions, ensuring learning materials are appropriate, identifying cues about marking schemes and organizing time and effort to attain the highest possible grades.

While deep learning is desired, it is not readily attainable given the nature of accounting education characterized by ever-expending volumes of standards to be covered in lectures. This study theorizes that the three learning approaches are not distinct. The psychology literature evidences that contextual information is required and desired to comprehend the underlying meanings (Goldstone \& Barsalou, 1998). Detailed contextual information enables the impact of one information item to be considered in conjunction with the impact of other information items for meanings to emerge (Lau, 2014). This study posits that surface learning constitutes the first step towards deep learning. Being equipped with accounting rules and procedures in learners' memory enables the rules and procedures to be considered in conjunction with one another for the underlying accounting fundamentals to emerge. This study posits that surface learning facilitates both strategic and deep learning. The goal of attaining the highest possible grades is short-term and more readily attainable compared with quest for meanings. Furthermore, bad grades undermine learners' mental and emotional well-being; decreased mental and emotional well-being brings about various health concerns such as stress, anxiety and depression (Crocker et al., 2003). Quest for meanings and appreciation of accounting fundamentals become less of a concern when learners are grappling with decreased mental and emotional well-being. This study posits that surface learning first facilitates adoption of strategic learning and subsequently deep learning.

\section{Method}

This study conducted a survey using the Approaches and Study Skills Inventory for Students (ASSIST) questionnaire to measure learning approaches. The ASSIST questionnaire is a more refined version of the Approaches to Studying Inventory (ASI) questionnaire. The ASSIST questionnaire has been validated and found useful across countries and cultures (e.g. Entwistle et al., 2000; Entwistle et al., 2001; Entwistle \& McCune, 2004). A total of 153 accounting undergraduates at a public university in Malaysia completed the ASSIST questionnaire. 50 were first year, 50 were second year, three were third year and 50 were fourth year accounting undergraduates; the questionnaire survey was administered at a time where third year accounting undergraduates were off-campus for industry placement. 
Table 1 shows the correlations between variables of interest in this study. The three dependent variables - surface, strategic and deep learning — are highly correlated with Pearson correlations greater than 0.8. Such high correlations are as theorized; the three learning approaches are not distinct where surface learning facilitates strategic learning and subsequently deep learning. Conception of learning is positively correlated with the three learning approaches, which suggests that undergraduates' understanding of what learning is influences choice of learning approaches. Preferences for both deep and surface learning are also positively correlated with the three learning approaches. Gender is coded as 0 for female and 1 for male. Gender is negatively correlated with the three learning approaches, which indicates that females are more certain that they adopt the three learning approaches. The negative correlations between gender and preferences for both deep and surface learning indicate that female undergraduates prefer both learning approaches more than their male counterparts.

\section{Table 1}

Pearson correlations

\begin{tabular}{|c|c|c|c|c|c|c|c|c|}
\hline & Surf & Str & Deep & CL & PDeep & PSurf & CGPA & G \\
\hline Surface learning (Surf) & 1 & & & & & & & \\
\hline Strategic learning (Str) & $0.847^{* *}$ & 1 & & & & & & \\
\hline Deep learning (Deep) & $0.852^{* *}$ & $0.929^{* *}$ & 1 & & & & & \\
\hline Conception of learning (CL) & $0.275^{* *}$ & $0.371^{* *}$ & $0.419^{* *}$ & 1 & & & & \\
\hline Preference for deep learning (PDeep) & $0.678^{* *}$ & $0.751^{* *}$ & $0.793^{* *}$ & $0.320^{* *}$ & 1 & & & \\
\hline Preference for surface learning (PSurf) & $0.702^{* *}$ & $0.627^{* *}$ & $0.658^{* *}$ & $0.191^{*}$ & $0.596^{* *}$ & 1 & & \\
\hline CGPA & 0.010 & 0.043 & 0.024 & -0.028 & -0.035 & -0.041 & 1 & \\
\hline Gender (G) & $-0.226^{* *}$ & $-0.224^{* *}$ & $-0.178^{*}$ & $0.205^{*}$ & $-0.174^{*}$ & $-0.222^{* *}$ & -0.024 & 1 \\
\hline
\end{tabular}

\section{Results}

A step-down procedure was conducted to assess the effects of the independent variables on each learning approach. First, analysis of covariance (ANCOVA) was conducted to assess the effects of the independent variables on surface learning. Table 2 presents a summary of the ANCOVA results. The effects of preferences for both deep and surface learning on adoption of surface learning are significant, $\mathrm{p}<0.05$.

Table 2

ANCOVA for surface learning

\begin{tabular}{lcccc}
\hline Source & df & MS & F & p \\
\hline Conception of learning & 1 & 61.493 & 1.011 & 0.317 \\
Preference for deep learning & 1 & 249.576 & 4.104 & $0.045^{*}$ \\
Preference for surface learning & 1 & 850.325 & 13.981 & $0.000^{* *}$ \\
CGPA & 1 & 9.849 & 0.162 & 0.688 \\
Gender & 1 & 43.304 & 0.712 & 0.401 \\
Error & 115 & & &
\end{tabular}

**Significant at 1 percent level

* Significant at 5 percent level

Second, ANCOVA was conducted to assess the effects of the independent variables on strategic learning, while controlling for the effect of surface learning. Table 3 provides a summary of the ANCOVA results. The effect of surface learning on strategic learning is highly significant, $\mathrm{p}<0.01$, which suggests that memorization of accounting rules and procedures at the beginning facilitates adoption of strategic learning to attain the highest possible grades. Having controlled for the effect of surface learning, the effect of preference for deep learning on strategic learning is highly significant, 
$\mathrm{p}<0.01$, which suggests that having a preference to seek meanings positively affect adoption of strategic learning.

\section{Table 3}

ANCOVA for strategic learning

\begin{tabular}{|c|c|c|c|c|}
\hline Source & df & MS & $\mathrm{F}$ & $\mathrm{p}$ \\
\hline Conception of learning & 1 & 91.935 & 1.354 & 0.247 \\
\hline Preference for deep learning & 1 & 1329.608 & 19.589 & $0.000 * *$ \\
\hline Preference for surface learning & 1 & 5.929 & 0.087 & 0.768 \\
\hline CGPA & 1 & 40.440 & 0.596 & 0.442 \\
\hline Gender & 1 & 35.711 & 0.526 & 0.470 \\
\hline Surface learning & 1 & 2648.010 & 39.012 & $0.000 * *$ \\
\hline Error & 114 & & & \\
\hline
\end{tabular}

Finally, ANCOVA was conducted to assess the effects of the independent variables on deep learning while controlling for the effects of surface and strategic learning. Table 4 provides a summary of the ANCOVA results. The effect of surface learning is significant, $\mathrm{p}<0.05$, while the effect of strategic learning is highly significant, $\mathrm{p}<0.01$; memorization of accounting rules and procedures as well as organizing learning materials, time and effort in a manner to attain the highest possible grades facilitate undergraduates' quest for meanings. Having controlled for the effects surface and strategic learning, the effect of preference for deep learning is highly significant, $\mathrm{p}<0.01$.The effect of gender is also significant, $\mathrm{p}<0.05$. Parameter estimates reveal that female undergraduates adopt deep learning more than their male counterparts; $\beta=-2.320, \mathrm{SE}=1.134, \mathrm{t}=-2.046, \mathrm{p}=0.043$.

\section{Table 4}

ANCOVA for deep learning

\begin{tabular}{lcccc}
\hline Source & df & MS & F & P \\
\hline Conception of learning & 1 & 14.819 & 0.665 & 0.417 \\
Preference for deep learning & 1 & 356.252 & 15.879 & $0.000^{* *}$ \\
Preference for surface learning & 1 & 13.504 & 0.602 & 0.439 \\
CGPA & 1 & 1.334 & 0.059 & 0.808 \\
Gender & 1 & 93.909 & 4.186 & $0.043^{*}$ \\
Surface learning & 1 & 132.026 & 5.882 & $0.017^{*}$ \\
Strategic learning & 1 & 1551.187 & 69.142 & $0.000^{* *}$ \\
\hline Error & 113 & & & \\
\hline **Significant at 1 percent level & & & &
\end{tabular}

\section{Conclusion}

This study helps to clarify concerns about business schools' disconnection from practice and graduates' incompetence as accounting syllabuses become increasingly burdened with factual accounting standards to be memorized and regurgitated in examinations. This study demonstrates that rote memorization and thus surface learning is not completely useless as it constitutes the first step towards deep learning. Results reveal that quests for meanings and being able to cope with new and complex situations in everyday life, which deep learning enables, is not easy to attain though not impossible. Memorization of accounting rules and procedures, which surface learning promotes, facilitates analyses of past examinations, prediction of examination questions and adoption of other strategic learning techniques to attain the highest possible grades. Having attained the highest possible grades promotes mental and emotional well-being, which facilitates adoption of deep learning to appreciate the 
meanings and fundamental accounting principles applicable across situational contexts. Results also suggest that having a preference for deep learning is important to motivate undergraduates to proceed from surface to strategic learning and finally deep learning. Female undergraduates have been found to be more inclined to adopt deep learning. As learning is a complex, life-long process that takes place every day on and off-campus (Cleary et al., 2007), future research can consider exploring to what extent specific on and off campus experiences promote deep learning.

\section{Acknowledgement}

The authors would like to thank the anonymous referees for constructive comments on earlier version of this paper.

\section{References}

Beattie, V., Collins, B., \& McInnes, B. (1997). Deep and surface learning: A simple or simplistic dichotomy? Accounting Education: An International Journal, 6 (1), 1-12.

Bennis, W., \& O’Toole, J. (2005). How business schools lost their way. Education. Harvard Business Review (May).

Cleary, M., Flynn, R., Thomasson, S., Alexander, R., \& McDonald, B. (2007). Graduate Employability Skills: Prepared for the Business, Industry and Higher Education Collaboration Council (August). Commonwealth of Australia http://www.dest.gov.au/highered/bihecc

Crocker, J., Karpinski, A., Quinn, D. M., \& Chase, S. K. (2003). When grades determine self-worth: Consequences of contingent self-worth for male and female engineering and psychology majors. Journal of Personality and Social Psychology, 85 (3), 507-516.

Eckhardt, J., \& Wetherbe, J. C. (2014). Making business school research more relevant. Business Education. Harvard Business Review (December 24).

Entwistle, N. J. (1987). Understanding classroom learning. Hodder and Stoughton.

Entwistle, N. (1988). Motivational factors in students' approaches to learning. InLearning strategies and learning styles (pp. 21-51). Springer US.

Entwistle, N., \& Tait, H. (1990). Approaches to learning, evaluations of teaching, and preferences for contrasting academic environments. Higher education, 19(2), 169-194.

Entwistle, N., Tait, H., \& McCune, V. (2000). Patterns of response to an approaches to studying inventory across contrasting groups and contexts.European Journal of Psychology of Education, 15(1), 33-48.

Entwistle, N., McCune, V., \& Walker, P. (2001). Conceptions, styles and approaches within higher education: analytic abstractions and everyday experience. Perspectives on thinking, learning, and cognitive styles, 103-136.

Entwistle, N., \& McCune, V. (2004). The conceptual bases of study strategy inventories. Educational Psychology Review, 16(4), 325-345.

Goldstone, R. L., \& Barsalou, L. W. (1998). Reuniting perception and conception. Cognition, 65, 231262.

Lau, Y. W. (2014). Aggregated or Disaggregated Information First? Journal of Business Research, 67 (11), 2376-2384.

Lowden, K., Hall, S., Elliot, D., \& Lewin, J. (2011). Employers’ perceptions of the employability skills of new graduates. London: Edge Foundation.

Marton, F., Hounsell, D., \& Entwistle, N. J. (Eds.). (1984). The experience of learning (pp. 36-55). Edinburgh: Scottish Academic Press.

Newble, D. I., \& Entwistle, N. J. (1986). Learning styles and approaches: implications for medical education. Medical Education, 20(3), 162-175.

Richardson, J. T. E. (2005). Students' approaches to learning and teachers' approaches to teaching in higher education. Educational Psychology, 25 (6), 673-680. 
Sunder, S., (2010). Adverse effects of uniform written reporting standards on accounting practice, education, and research. Journal of Accounting and Public Policy, 29 (2), 99-114. 